\title{
The assimilation of ammonia nitrogen by bacteria of the rumen of sheep
}

\author{
By A. T. PHILLIPSON, MARJORIE J. DOBSON, T. H. BLACKBURN \\ AND MILDRED BROWN \\ Rowett Research Institute, Bucksburn, Aberdeen \\ (Received I6 Fanuary 196I-Revised 6 November I961)
}

McDonald ( 1952 ) discussed the role of ammonia in the rumen and pointed out that many kinds of bacteria are not fastidious in their nitrogen requirements, and that in the rumen growth of bacteria that use ammonia as a source of $\mathrm{N}$ is to be expected.

Much work has been done on the use of non-protein $\mathrm{N}$, especially of urea, in the feeding of ruminants, and there is now no doubt that the $\mathrm{N}$ of many simple nitrogenous compounds can be incorporated in bacterial protein and so be of value to the animal. The work of Pearson \& Smith (I943) showed that, in incubated rumen liquor, urea was rapidly hydrolysed to ammonia, and provided evidence that protein was being formed from ammonia by the rumen bacteria. The ability of rumen bacteria to grow with ammonia as their sole or part source of $\mathrm{N}$ has not been closely investigated, and although organisms have been classified according to their ability to ferment carbohydrates or to deaminate amino acids, their ability to assimilate ammonia- $\mathrm{N}$ has only recently received attention, in particular from Bryant (I96I).

The fact that the addition of starch to a protein-rich diet depressed the concentration of ammonia present in the rumen (McDonald, 1952; Chalmers \& Synge, 1954; Annison, Chalmers, Marshall \& Synge, 1954) suggested that starch-fermenting bacteria in particular might possess the property of using ammonia- $\mathrm{N}$ for growth. The experiments described here were undertaken to find whether it were so. A brief preliminary account of the work has already been published (Phillipson, Dobson \& Blackburn, 1959).

\section{METHODS}

The work was done in three stages: (I) the examination of the changes in ammonia concentration occurring during short in vitro incubations of rumen liquor from sheep receiving various diets; (2) the isolation and examination of starch- and glucosefermenting bacteria from rumen liquor; and (3) the assessment of the concentration of such bacteria in rumen liquor by plate counts of the colonies formed from suitable dilutions of the rumen liquor of sheep receiving food containing different quantities of starch and protein.

Animals and diets. Adult Cheviot and Blackface sheep were used and they were all fitted with permanent ebonite rumen cannulas.

The diets were as follows:

(I) fresh grass-sheep were maintained on early summer or autumn pasture; 
(2) meadow hay to a maximum of I $\mathrm{kg}$ daily;

(3) chopped meadow hay $400 \mathrm{~g}$, and sliced fodder beet $600 \mathrm{~g}$;

(4) chopped meadow hay $150 \mathrm{~g}$, with a concentrate mixture (FM) I000 g (FM consisted of $900 \mathrm{~g}$ flaked maize, $95 \mathrm{~g}$ maize gluten meal, $3 \mathrm{~g}$ steamed bone flour and $2 \frac{1}{2} \mathrm{~g}$ salt);

(5) chopped meadow hay $440 \mathrm{~g}$, and groundnut meal (G) $560 \mathrm{~g}$;

(6) chopped meadow hay $\mathrm{r} 5 \circ \mathrm{g}$, with $(a) 75^{\circ} \mathrm{g} \mathrm{FM}$ and $25^{\circ} \mathrm{g} \mathrm{G}\left(\mathrm{FM}_{3}\right),(b) 500 \mathrm{~g}$ FM and $500 \mathrm{~g} \mathrm{G}$ (FM 2), or (c) $250 \mathrm{~g} \mathrm{FM}$ and $75^{\circ} \mathrm{g} \mathrm{G}$ (FM I);

(7) chopped meadow hay $440 \mathrm{~g}$, with $(a),(b)$ or $(c)$ reduced from 1000 to $560 \mathrm{~g}$.

The sheep were fed daily at 7 a.m., I I. 30 a.m. and 4 p.m. With diets 4 and 6 half the concentrate mixture was given at 7 a.m. and the other half at II.3O a.m., and the hay was given at 4 p.m. With diets 3,5 and 7 the individual constituents were thoroughly mixed and $35^{\circ} \mathrm{g}$ were given at 7 and I I a.m. and $300 \mathrm{~g}$ at $4 \mathrm{p}$.m.

Sampling. Samples of rumen liquor were withdrawn between 9.30 and ro.o a.m. except when otherwise stated. A plastic sampling tube was thrust well down into the ventral sac so that rumen liquor entered the lower end of the tube. The upper end was then closed with the thumb and the sample lifted from the rumen and run into a flask through which carbon dioxide was flowing. About $250 \mathrm{ml}$ were withdrawn in this way. The flask was stoppered with a rubber bung.

In vitro incubations. The rumen liquor was rapidly filtered through four layers of surgical gauze and $100 \mathrm{ml}$ portions were pipetted into $25^{\circ} \mathrm{ml}$ conical flasks which were stoppered with rubber bungs carrying inlet and outlet glass tubing with rubber tubing closed by screw clips. In the initial experiments four flasks from each sample were set up: two flasks contained the rumen liquor alone and one of them was rapidly heated to bring the liquor to the boil and cooled; $5 \mathrm{ml}$ of a solution of ammonium chloride containing approximately $40 \mathrm{mg}$ of ammonia- $\mathrm{N}$ were added to each of the other two flasks, one of which was rapidly heated to bring the contents to the boil and cooled to serve as a control. In the initial experiments (Table I) larger quantities of ammonium chloride corresponding to $9^{\mathrm{I}}$ or $86 \mathrm{mg}$ ammonia-N were added. In later experiments heated control flasks were dispensed with as unnecessary. The flasks were thoroughly gassed with carbon dioxide and incubated at $37^{\circ}$. The screw clips were opened periodically to release excess gas formed within the flasks during incubation. When samples were withdrawn at intervals during the incubation, the flasks were regassed. Initially incubations lasted for $4 \mathrm{~h}$, but later a period of $2 \frac{1}{2} \mathrm{~h}$ was adopted.

Ammonia- $N$. The method was that of Conway \& O'Malley (1942), using the boric acid solution in the centre well. Titrations were done with a Conway burette with $0.02 \mathrm{~N}-\mathrm{HCl}$. Duplicate estimations were made throughout; the standard error of the titration was $\pm 0.003 \mathrm{ml}$.

Protein- $N$. In all experiments, except those involving ${ }^{15} \mathrm{~N}$, protein- $\mathrm{N}$ was taken as being the difference between the total $\mathrm{N}$ and that not precipitated by $10 \%$ trichloroacetic acid. Rumen liquor, $5 \mathrm{ml}$, was pipetted into a $100 \mathrm{ml}$ volumetric flask and diluted to $100 \mathrm{ml}$ with $10 \%(\mathrm{w} / \mathrm{v})$ trichloroacetic acid. The flask was allowed to stand overnight and the contents were then filtered through Whatman no. $4^{2}$ filter-paper. 
Whenever difficulty was encountered in obtaining clear filtrates the material was discarded. The $\mathrm{N}$ contents of the rumen liquor and filtrate were determined by the Kjeldahl procedure. The digests were distilled in Markham stills, the boric acid reagent of Conway \& O'Malley being used to receive the distillate.

Volatile fatty acids. Rumen contents were steam distilled in the presence of an equal volume of the reagent of McAnally (1944). The distillates were titrated with $0.02 \mathrm{~N}-\mathrm{NaOH}$ under carbon dioxide-free conditions. The distillates were evaporated to dryness and extracted by the method of Annison (1954) and the volatile fatty acids were partitioned by gas chromatography (James \& Martin, 1952).

Lactic acid. This acid was determined by the method of Barker \& Summerson (194I).

Culture methods. A phosphate buffer made by mixing $0.14 \mathrm{M}-\mathrm{Na}_{2} \mathrm{HPO}_{4}$ and $0.14 \mathrm{M}-\mathrm{KH}_{2} \mathrm{PO}_{4}$ in the proportions by volume of $\mathrm{I}: 7$ was used as the basis of the medium. The media were made from stock solutions containing $(\mathrm{w} / \mathrm{v}) \mathrm{NH}_{4} \mathrm{Cl}$ i $5.2 \%$, glucose $18.0 \%$, anhydrous sodium acetate $20.5 \%$, sodium citrate $\left(2 \mathrm{H}_{2} \mathrm{O}\right) 20.0 \%$, $\mathrm{n}$-valeric acid $0.5 \%$, and isovaleric acid $0.25 \%$. Twenty $\mathrm{ml}$ of the acetate solution and $10 \mathrm{ml}$ of each of the other solutions were added to $500 \mathrm{ml}$ of the phosphate buffer. A trace-element solution was added (ro ml) containing (w/v) $\mathrm{MnSO}_{4} \cdot{ }_{4} \mathrm{H}_{2} \mathrm{O} \mathrm{I}_{4} \%$, $\mathrm{MgSO}_{4} \cdot 7 \mathrm{H}_{2} \mathrm{O} 5.6 \%, \mathrm{FeSO}_{4} \cdot{ }_{7} \mathrm{H}_{2} \mathrm{O} 0.34 \%, \mathrm{CoCl}_{2} \cdot 6 \mathrm{H}_{2} \mathrm{O} 0.015 \%$ and $\mathrm{CuSO}_{4} \cdot 5 \mathrm{H}_{2} \mathrm{O}$ $0.15 \%$, and a solution of $\mathrm{B}$ vitamins (10 $\mathrm{ml}$ ) containing, per l., Ca-D-pantothenate I00 $\mathrm{mg}$, nicotinic acid $250 \mathrm{mg}$, folic acid I $\mathrm{mg}$, biotin $0.1 \mathrm{mg}$, thiamine hydrochloride I00 $\mathrm{mg}, p$-aminobenzoic acid $100 \mathrm{mg}$, pyridoxine $100 \mathrm{mg}$, riboflavin $100 \mathrm{mg}$, and cyanocobalamin $0.05 \mathrm{mg}$. Agar (G. T. Gurr Ltd, London, S.W. 6), $0.75 \mathrm{~g}$ for liquid media or $15 \mathrm{~g}$ for solid media, was added dissolved in $390 \mathrm{ml}$ water, together with $5 \mathrm{~g}$ soluble starch suspended in $10 \mathrm{ml}$ water. The whole was autoclaved at $120^{\circ}$ for $15 \mathrm{~min}$, and finally before use ro $\mathrm{ml}$ of $5 \%(\mathrm{w} / \mathrm{v})$ L-cysteine freshly filtered through a Seitz filter (Carlson Ltd, I Great Eastern Street, London, E.C. 2) grade E.K. were added. This medium is hereafter referred to as 'normal' medium. 'The same medium was used also after the addition of $5 \mathrm{~g}$ Bacto-peptone (Difco Laboratories Inc., Detroit, U.S.A.) before sterilization. This medium is hereafter referred to as 'peptone' medium.

The normal medium was approximately a $0.17 \mathrm{M}$ solution with a $\mathrm{pH}$ close to 6 . Of the $\mathrm{N}$ present, $87 \cdot \mathrm{I} \%$ was contributed by ammonium chloride, $\mathrm{I} 2 \cdot 7 \%$ by L-cysteine and $0.2 \%$ by $\mathrm{B}$ vitamins. The liquid medium in screw-cap bottles was thoroughly gassed with oxygen-free carbon dioxide before inoculation. Incubation was done at $37^{\circ}$. Plates were incubated in a McIntosh and Fildes pattern anaerobic jar (Gallenkamp and Towers, Sun Street, London) filled after evacuation with hydrogen containing $5 \% \mathrm{CO}_{2}$. Residual oxygen was removed by 'sparking' in the usual way.

Both normal and peptone media were used in order to establish whether cultures grown from single colonies isolated from the peptone media had different $\mathrm{N}$ requirements from those isolated from normal media. Initially growth in liquid media was judged by eye at 24, 48 and $72 \mathrm{~h}$ after subculture. The disappearance of starch and glucose, the amounts of volatile and lactic acids formed, and the change in the concentration of ammonia- $\mathrm{N}$ were estimated after $72 \mathrm{~h}$. In later experiments growth was 
estimated solely by eye and compared with the change in ammonia concentration after incubation for $72 \mathrm{~h}$.

The methods used to identify non-coccoid cultures are given on p. 159 .

The medium used to examine the fermentation of glucose was a modification of that of Baumann \& Foster (1956) containing: Bacto-casitone (Difco Laboratories Inc., Detroit, U.S.A.) Io g; yeast extract $5 \mathrm{~g}, \mathrm{MgSO}_{4} \cdot 7 \mathrm{H}_{2} \mathrm{O} 0.2 \mathrm{~g}, \mathrm{KH}_{2} \mathrm{PO}_{4} 5.0 \mathrm{~g}$, $\mathrm{Na}_{2} \mathrm{HPO}_{4} \mathrm{I} \cdot \mathrm{O} \mathrm{g}$, cysteine hydrochloride $0.2 \mathrm{~g}$, resazurin $0.00 \mathrm{I} \mathrm{g}$, agar I g, water to $900 \mathrm{ml}$; the $\mathrm{pH}$ was $7 \cdot 0$. Portions of $190 \mathrm{ml}$ were autoclaved with $2 \mathrm{~g} \mathrm{CaCO}_{3}$ under $\mathrm{CO}_{2}$. Sterile glucose solutions ( $10 \mathrm{ml}$ ) were added and the medium was then inoculated.

Counting. Suitable dilutions of rumen liquor up to $10^{-8}$ were made with the phosphate buffer. Medium containing $\mathrm{r} \cdot 5 \%$ agar was inoculated and poured into Petri dishes and colony counts were made after incubation for $72 \mathrm{~h}$. Three plates at each dilution, usually $10^{-6}$, $10^{-7}$ and $10^{-8}$, were used per count and the mean value for the dilution giving a two-figure count was taken as most representative.

\section{RESULTS}

\section{Changes in rumen liquor during incubation with added ammonium chloride}

Rumen liquor from sheep receiving hay and FM contained very little ammonia ('Table I). In all the experiments, ammonium chloride was accordingly added to the liquor before incubation. The effect of this addition can be seen in Table $\mathrm{x}$. When rumen liquor from sheep receiving grass was incubated with ammonium chloride for $4 \mathrm{~h}$, the concentration of ammonia- $\mathrm{N}$ in the liquor increased. With rumen liquor from sheep receiving hay and FM the concentration decreased (Table I). There was evidence of an initial small rapid decrease in concentration of ammonia- $N$ in some

Table I. Changes in ammonia-nitrogen concentration $(\mathrm{mg} / \mathrm{I} / \mathrm{co} \mathrm{ml})$ in the rumen liquor of sheep fed on grass or on a hay and flaked-maize mixture (FM) when the liquor was fermented for $4 h$ at $37^{\circ}$ under $\mathrm{CO}_{2}$, with and without added ammonium chloride (9 I or $86 \mathrm{mg} / \mathrm{I} 00 \mathrm{ml}$ )

\begin{tabular}{|c|c|c|c|c|c|c|c|}
\hline \multirow{3}{*}{$\begin{array}{c}\text { Expt } \\
\text { no. } \\
\text { I }\end{array}$} & \multirow{3}{*}{$\begin{array}{c}\text { Addition } \\
\text { to } \\
\text { liquor } \\
\text { before } \\
\text { incubation } \\
\text { None } \\
\mathrm{NH}_{4} \mathrm{Cl}\end{array}$} & \multicolumn{3}{|c|}{ Grass diet } & \multicolumn{3}{|c|}{ Hay + FM diet } \\
\hline & & $\begin{array}{c}\text { Before } \\
\text { incubation }\end{array}$ & $\begin{array}{c}\text { After } \\
\text { incubation }\end{array}$ & Change & $\begin{array}{c}\text { Before } \\
\text { incubation }\end{array}$ & $\begin{array}{c}\text { After } \\
\text { incubation }\end{array}$ & Change \\
\hline & & $\begin{array}{r}16 \cdot 0 \\
109 \cdot 2\end{array}$ & $\begin{array}{r}27 \cdot 7 \\
\mathrm{I} 13 \cdot 6\end{array}$ & $\begin{array}{r}+\mathrm{II} \cdot 7 \\
+4 \cdot 4\end{array}$ & $\begin{array}{r}0.7 \\
89.1\end{array}$ & $\begin{array}{r}0.3 \\
60.9\end{array}$ & $\begin{array}{r}-0.4 \\
-28 \cdot 2\end{array}$ \\
\hline 2 & $\begin{array}{l}\text { None } \\
\mathrm{NH}_{4} \mathrm{Cl}\end{array}$ & $\begin{array}{r}21 \cdot 4 \\
103 \cdot 9\end{array}$ & $\begin{array}{r}31 \cdot 6 \\
\text { II } 4 \cdot 8\end{array}$ & $\begin{array}{l}+10.2 \\
+10.9\end{array}$ & $\begin{array}{r}0.6 \\
86 \cdot 0\end{array}$ & $\begin{array}{r}0.3 \\
77 \cdot 6\end{array}$ & $\begin{array}{l}-0.3 \\
-8.4\end{array}$ \\
\hline 3 & $\begin{array}{l}\text { None } \\
\mathrm{NH}_{4} \mathrm{Cl}\end{array}$ & $\begin{array}{r}29 \cdot 9 \\
113.9\end{array}$ & $\begin{array}{r}43 \cdot 5 \\
127 \cdot 7\end{array}$ & $\begin{array}{l}+13 \cdot 6 \\
+{ }_{13} \cdot 8\end{array}$ & $\begin{array}{r}3 \cdot 4 \\
90 \cdot 2\end{array}$ & $\begin{array}{r}0.3 \\
84.3\end{array}$ & $\begin{array}{l}-3 \cdot I \\
-5 \cdot 9\end{array}$ \\
\hline 4 & $\begin{array}{l}\text { None } \\
\mathrm{NH}_{4} \mathrm{Cl}\end{array}$ & $\begin{array}{r}28 \cdot 5 \\
113 \cdot 7\end{array}$ & $\begin{array}{r}42 \cdot 8 \\
125 \cdot 2\end{array}$ & $\begin{array}{l}+14.3 \\
+11 \cdot 5\end{array}$ & $\begin{array}{r}0.7 \\
83.6\end{array}$ & $\begin{array}{r}0.5 \\
77.0\end{array}$ & $\begin{array}{l}-0.2 \\
-6.6\end{array}$ \\
\hline 5 & $\begin{array}{l}\text { None } \\
\mathrm{NH}_{4} \mathrm{Cl}\end{array}$ & $\begin{array}{r}23 \cdot 4 \\
109 \cdot 6\end{array}$ & $\begin{array}{r}32 \cdot 2 \\
\text { II } 8 \cdot 4\end{array}$ & $\begin{array}{l}+8 \cdot 8 \\
+8 \cdot 8\end{array}$ & $\begin{array}{r}3 \cdot 0 \\
86 \cdot 7\end{array}$ & $\begin{array}{r}0.4 \\
79 \cdot 0\end{array}$ & $\begin{array}{l}-2 \cdot 6 \\
-7 \cdot 7\end{array}$ \\
\hline
\end{tabular}


experiments. It may have been due to rapid uptake of ammonia- $\mathrm{N}$ by bacterial cells, but other explanations, in addition to analytical ones, cannot be excluded.

Serial sampling from incubations of the rumen liquor of sheep fed on hay and FM showed that $2 \frac{1}{2} \mathrm{~h}$ sufficed to obtain measurable changes, and this period was used in all subsequent experiments since it was desirable for the period to be as short as possible to prevent distortion of the mixed culture present.

Incubations of the rumen liquor of sheep fed on hay alone or on hay and fodder beet showed comparatively small changes in the concentrations of ammonia- $\mathrm{N}$; small increases occurred in the liquor of sheep fed on hay, and small losses usually occurred in the liquor of sheep fed on hay and fodder beet (Table 2). Fodder beet contains appreciable quantities of soluble sugars and, since these are likely to be fermented

Table 2. Changes in ammonia-nitrogen concentration $(\mathrm{mg} / \mathrm{1} 00 \mathrm{ml})$ in the rumen liquor of sheep fed on hay or on hay and fodder beet when the liquor was incubated for $2 \frac{1}{2} h$ at $37^{\circ}$ under $\mathrm{CO}_{2}$ with added ammonium chloride $(40 \mathrm{mg} / \mathrm{100} \mathrm{ml}$ )

\begin{tabular}{|c|c|c|c|c|c|}
\hline \multirow[b]{2}{*}{ Diet } & \multirow{2}{*}{$\begin{array}{l}\text { No. of } \\
\text { observa- } \\
\text { tions }\end{array}$} & \multicolumn{2}{|c|}{$\begin{array}{l}\text { Initial concentration } \\
\text { in the liquor* }\end{array}$} & \multicolumn{2}{|c|}{ Change after $2 \frac{1}{2} \mathrm{~h}$} \\
\hline & & Range & Mean & Range & Mean \\
\hline Hay & 6 & $2 \cdot 7-13 \cdot 6$ & $7 \cdot 5$ & $+1 \cdot 0-+3 \cdot 2$ & $+2 \cdot 4$ \\
\hline Hay and fodder beet & 12 & $14 \cdot 6-35 \cdot 0$ & $20 \cdot 7$ & $+I \cdot 2--6 \cdot I$ & $-I \cdot 7$ \\
\hline $\begin{array}{l}\text { Hay and fodder beet: } † \\
\text { Before feeding } \\
\text { After feeding }\end{array}$ & $\begin{array}{l}4 \\
4\end{array}$ & $\begin{array}{r}8 \cdot 1-11 \cdot 2 \\
16 \cdot 8-22 \cdot 7\end{array}$ & $\begin{array}{r}8 \cdot 8 \\
19 \cdot 1\end{array}$ & $\begin{array}{r}+0.3^{-+3}+3 \cdot 4 \\
0--2 \cdot 4\end{array}$ & $\begin{array}{l}+1 \cdot 7 \\
-I \cdot 6\end{array}$ \\
\hline
\end{tabular}

* Before the addition of ammonium chloride.

$\uparrow$ Samples were taken from four sheep between 6.50 a.m. and 7.10 a.m., immediately before feeding, and again between 8.30 and 8.45 a.m., approximately $75^{-90}$ min after feeding.

Table 3. Effect of varying the type of concentrate in mixed diets for sheep on the ammonianitrogen concentration $(\mathrm{mg} / \mathrm{r} 00 \mathrm{ml})$ in the rumen liquor and on the change in this concentration during incubation of the rumen liquor for $2 h$ at $37^{\circ}$ with added ammonium chloride $(40 \mathrm{mg} / 100 \mathrm{ml})$

\begin{tabular}{|c|c|c|c|c|}
\hline Expt & No. of sheep & $\begin{array}{c}\text { Diet: type of } \\
\text { concentrate added } \\
\text { to hay* }\end{array}$ & $\begin{array}{l}\text { Concentration } \\
\text { of ammonia- } N \text { in } \\
\text { rumen liquor }\end{array}$ & $\begin{array}{l}\text { Change in concentra- } \\
\text { tion of ammonia- } N \text { in } \\
\text { rumen liquor after } \\
\text { incubation }\end{array}$ \\
\hline A & $\begin{array}{l}\mathbf{I} \\
\mathbf{I} \\
\mathbf{I} \\
\mathbf{I}\end{array}$ & $\begin{array}{l}F M \\
\mathrm{FM}_{3} \\
\mathrm{FM}_{2} \\
\mathrm{FM}_{1} \\
\mathrm{G}\end{array}$ & $\begin{array}{r}I \cdot I \\
23 \cdot 0 \\
37 \cdot 7 \\
62 \cdot 4 \\
67 \cdot 4\end{array}$ & $\begin{array}{r}-7.9 \\
-0.1 \\
+6.1 \\
+ \text { I } 3.4 \\
+ \text { II.5 }\end{array}$ \\
\hline $\mathrm{B}$ & $\begin{array}{l}2 \\
2 \\
2 \\
1\end{array}$ & $\begin{array}{c}\text { FM } \\
\text { FM2 } \\
\text { G } \\
\text { None }\end{array}$ & $\begin{array}{c}1 \cdot 25 \\
33 \cdot 6 \\
77 \cdot 5 \\
7 \cdot 6\end{array}$ & $\begin{array}{r}-8.0 \\
+12.5 \\
+35.6 \\
+2.4\end{array}$ \\
\hline \multicolumn{2}{|c|}{$\begin{array}{l}\text { Standard error of } \\
\text { differences between } \\
\text { treatment means in } \\
\text { Expt B }\end{array}$} & $\begin{array}{l}\text { Between pair means } \\
\text { Between pair means } \\
\text { and single value for }\end{array}$ & $\begin{array}{r}+6.0 \\
+7.7\end{array}$ & $\begin{array}{l}+3.16 \\
+3.87\end{array}$ \\
\hline
\end{tabular}


rapidly, a comparison of the liquor from the four sheep fed on this diet taken before and after the morning feed was made, and from Table 2 it will be seen that before feeding increases in ammonia occurred but after feeding decreases occurred.

A further comparison of the effect of the food on the changes that occurred in ammonia- $\mathrm{N}$ concentration during incubation was made with sheep that received diets in which FM was replaced by groundnut meal $(\mathrm{G})$ in varying proportions (p. I 52 ). Two experiments were done and the starch- and glucose-fermenting bacteria were counted in the second experiment. The initial ammonia concentrations before addition of ammonium chloride and the net changes occurring in vitro are given in Table 3 .

The differences in the results shown in Table 3 between the single sheep fed on each diet in Expt A cannot be analysed for treatment differences since only one sheep was used per diet, but they show the same trend as the pairs of sheep used in Expt B although the differences were not so marked. The differences between the means for pairs of sheep in Expt B were significant at the $I \%$ level. The difference between the mean change in ammonia- $\mathrm{N}$ for the single sheep receiving hay in Expt $\mathrm{B}$ was significant by difference at the I \% level only from the mean for the pair of sheep receiving hay and groundnut meal. The differences between the mean concentration of ammonia- $\mathrm{N}$ for the single sheep and for the pairs of sheep receiving FM 2 and $\mathrm{G}$ were also significant at this level.

\section{Effects of inhibitors and antibiotics on the decrease in ammonia- $N$ during in vitro incubation}

Sodium azide, potassium cyanide and 2,4-dinitrophenol were tested to see whether addition of these agents in concentrations of Io $\mathrm{mm}$ to rumen liquor would inhibit the decrease in ammonia nitrogen that normally occurred. Liquor taken from sheep fed on hay and FM was used. Sodium azide inhibited the decrease of ammonia-N by about $80 \%$ when in comparison with the control; potassium cyanide and 2,4-dinitrophenol reduced it by about $50 \%$.

Table 4. Effect of penicillin, chlortetracycline or sulphanilamide on the decrease in ammonia-nitrogen concentration during $2 \frac{1}{2} h$ incubation of rumen liquor taken from a sheep fed on hay and the flaked maize mixture (FM)

\begin{tabular}{|c|c|c|c|}
\hline \multirow{2}{*}{$\begin{array}{l}\text { Concentration of } \\
\text { antibiotic } \\
\text { ( } \mu \mathrm{g} / \mathrm{ml} \text { rumen } \\
\text { liquor })\end{array}$} & \multicolumn{3}{|c|}{ Loss of ammonia- $\mathrm{N}(\mathrm{mg} / \mathrm{l} 00 \mathrm{ml})$} \\
\hline & Penicillin & Chlortetracycline & Sulphanilamide \\
\hline$\circ$ & $8 \cdot 8$ & $8 \cdot 7$ & II $\cdot 0$ \\
\hline 0.1 & $13 \cdot 2$ & $10 \cdot 0$ & $12 \cdot 4$ \\
\hline $1 \cdot 0$ & $8 \cdot 2$ & $8 \cdot 3$ & $\mathrm{II} \cdot 3$ \\
\hline 10.0 & 10.0 & $8 \cdot 2$ & I I. 4 \\
\hline $100 \cdot 0$ & $9 \cdot 4$ & $6 \cdot 1$ & 10.6 \\
\hline
\end{tabular}

The effects of penicillin, chlortetracycline and sulphanilamide were also tested on several occasions, but these agents had surprisingly little effect even in concentrations of $100 \mu \mathrm{g} / \mathrm{ml}$. In very low concentrations they appeared to cause a greater decrease in 
the concentration of ammonia-N (Table 4). Subsequently these agents were found to prevent growth of isolated cultures of starch- and glucose-fermenting bacteria and of Lactobacillus bifidus.

\section{Incorporation of ammonia- $N$ into the trichloroacetic acid precipitate of rumen liquor during incubation}

Estimates of total and non-protein $\mathrm{N}$ of the rumen liquor of sheep fed on hay and FM before and after incubation showed that whenever there was a large decrease of ammonia- $\mathrm{N}$ there was an increase in protein- $\mathrm{N}$ (Table 5). The values obtained, however, were differences between total and non-protein $\mathrm{N}$, and more critical evidence was sought to substantiate these estimates. In two experiments ammonia- $N$, enriched with ${ }^{15} \mathrm{~N}$, was added to the rumen liquor of a sheep fed on hay and FM before incubation. In the first experiment a threefold increase in the concentration of ${ }^{15} \mathrm{~N}$ was found

Table 5. Decrease $(\mathrm{mg} / \mathrm{100} \mathrm{ml})$ in ammonia-nitrogen in the rumen liquor of sheep fed on hay and the flaked maize mixture (FM), in relation to the protein formed, during incubation for $2 \frac{1}{2} h$ at $37^{\circ}$ under $\mathrm{CO}_{2}$ with added ammonium chloride $(40 \mathrm{mg} / \mathrm{roO} \mathrm{ml})$

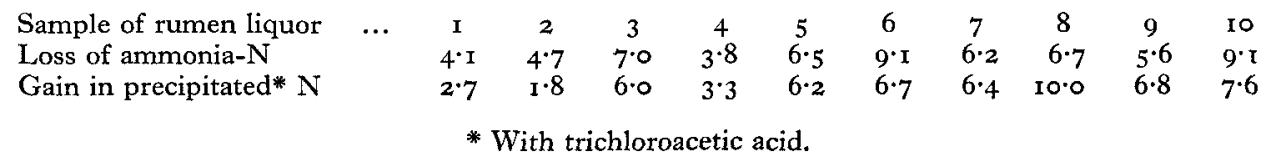

Table 6. Changes in the concentration of ${ }^{15} \mathrm{~N}$ in the trichloroacetic acid precipitate obtained from rumen liquor, and in the concentration of ammonia nitrogen during the incubation, for $2 \frac{1}{2} h$ at $37^{\circ}$ under $\mathrm{CO}_{2}$, of $40 \mathrm{mg}$ ammonium chloride/ $100 \mathrm{ml}$ with rumen liquor from sheep

\begin{tabular}{|c|c|c|c|c|}
\hline \multirow[b]{2}{*}{ Expt no. } & \multirow[b]{2}{*}{$\begin{array}{l}\text { Addition to } \\
\text { rumen liquor } \\
\text { before } \\
\text { incubation }\end{array}$} & \multicolumn{2}{|c|}{$\begin{array}{l}\text { Concentration of }{ }^{15} \mathrm{~N} \text { in } \\
\text { trichloroacetic acid precipitate }\end{array}$} & \multirow{2}{*}{$\begin{array}{l}\text { Change in } \\
\text { ammonia- } \mathrm{N} \\
\text { concentration } \\
\text { during incubation } \\
(\mathrm{mg} / \mathrm{1} 00 \mathrm{ml})\end{array}$} \\
\hline & & $\begin{array}{c}\text { Before } \\
\text { incubation* } \\
(\%)\end{array}$ & $\begin{array}{c}\text { After } \\
\text { incubation } \\
(\%)\end{array}$ & \\
\hline I & $\begin{array}{l}\mathrm{NH}_{4} \mathrm{Cl} \\
{ }^{15} \mathrm{NH}_{4} \mathrm{Cl}\end{array}$ & $\begin{array}{l}0.37 \\
0.38\end{array}$ & $\begin{array}{l}0.37 \\
1 \cdot 20\end{array}$ & $\begin{array}{r}-11 \cdot 7 \\
-8 \cdot 8\end{array}$ \\
\hline 2 & $\begin{array}{l}{ }^{15} \mathrm{NH}_{4} \mathrm{Cl}+\mathrm{NaN}_{3} \\
{ }^{15} \mathrm{NH}_{4} \mathrm{Cl}\end{array}$ & $\begin{array}{l}0.43 \\
0.39\end{array}$ & $\begin{array}{l}0.49 \\
0.52\end{array}$ & $\begin{array}{l}+3 \cdot 0 \\
+1 \cdot 0\end{array}$ \\
\hline
\end{tabular}

* Estimates of the abundance of ${ }^{15} \mathrm{~N}$ in cylinder nitrogen were made during the analyses of the various fractions in both experiments and the values found varied from 0.36 to $0.37 \%$.

in the trichloroacetic acid precipitate after incubation for $2 \frac{1}{2} \mathrm{~h}$ and the disappearance of ammonia- $\mathrm{N}$ was substantial. The natural abundance of ${ }^{15} \mathrm{~N}$ is $0.36 \%$ and estimates of the abundance in cylinder $\mathrm{N}_{2}$ gave values very close to this figure. Similarly, values found in the trichloroacetic acid precipitate in control flasks, to which no ${ }^{15} \mathrm{~N}$ was added, and in the precipitate of liquor boiled before the addition of ammonium chloride enriched with ${ }^{15} \mathrm{~N}$, were also close to these values. In the second of these experiments a slight increase in the concentration of ammonia- $\mathrm{N}$ occurred during incubation, but even so there was a slight increase in the concentration of ${ }^{15} \mathrm{~N}$ in the 
trichloroacetic acid precipitate (Table 6). In the second experiment sodium azide was added to the control flask. It was unfortunate that the usual decrease of ammonia-N was not seen on this occasion and that the effect of such an inhibitor was so small. From the experiments with ${ }^{15} \mathrm{~N}$ there is no doubt that during incubation decreases in the concentration of ammonia- $\mathrm{N}$ indicate a synthesis of protein or of simpler nitrogenous compounds that are precipitated by trichloroacetic acid; there seems no way in which it can occur except by the assimilation of ammonia- $\mathrm{N}$ with subsequent synthesis of amino acids and protein within bacterial cells. Since this effect is not inhibited by penicillin, chlortetracycline or sulphanilamide and since it occurs in the short period of $2 \frac{1}{2} \mathrm{~h}$, it appears to be due to an increase in the complex $\mathrm{N}$-containing materials of existing cells rather than to multiplication of cells, and indicates that the intracellular enzyme systems concerned were not inhibited by the concentrations of penicillin, chlortetracycline or sulphanilamide introduced.

\section{Isolation and characterization of certain starch-and glucose-fermenting bacteria which assimilate ammonia- $N$}

A large number of isolates from single colonies grown on normal or peptone plates were made from the rumen liquor of sheep fed on $(a)$ hay and FM, $(b)$ hay, FM and G, $(c)$ hay and $\mathrm{G}$, and $(d)$ hay alone. Most of these organisms grew well in both normal and peptone liquid media but growth was usually more vigorous in the peptone medium. The quantity of ammonia- $\mathrm{N}$ disappearing from the medium was regularly determined and in normal media the extent of growth was closely related to the ammonia- $\mathrm{N}$ assimilated. The decrease in the concentrations of ammonia- $\mathrm{N}$ with those strains grown in normal medium was greater than with those grown in peptone media. After repeated subculture, strains grown in peptone media often caused increases rather than decreases in ammonia- $\mathrm{N}$ concentration, but when transferred back to normal media these strains again caused decreases in ammonia- $\mathrm{N}$ concentration (Fig. I).

The behaviour of the strains growing in peptone media may be explained in two ways: either they assimilated amino- $\mathrm{N}$ and accordingly used less ammonia- $\mathrm{N}$, or else they continued to assimilate ammonia- $\mathrm{N}$, in quantities similar to those of the strains maintained in normal media, but also deaminated amino acids, the extent of deamination tending to increase with succeeding generations. Under the second set of circumstances amino-N may still have been assimilated. The work of Warner (1955) suggests that all these processes may have occurred. Bryant (196I) observed that some $55 \%$ of the predominant strains of rumen organisms grow with either ammonia-N or amino- $\mathrm{N}$ and the bacteria studied by us appear to belong to this group. Isolates from colonies on either peptone or normal solid media grew in either of the liquid media and gave no indication of obligatory amino acid requirements other than for L-cysteine.

Examination of a single strain of the L. bifidus type isolated from a sheep fed on hay and FM for the relationship between the amount of ammonia- $\mathrm{N}$ assimilated and the amount in the trichloroacetic acid precipitate showed that rather more ammonia- $\mathrm{N}$ was lost from the medium in relation to the protein- $\mathrm{N}$ formed when this strain was 
grown in normal medium than when it was grown in peptone medium (Phillipson et al. I959).

Slender rods and cocci were examined but all possessed the property of assimilating ammonia-N. Other general properties of the strains examined in greater detail were that they fermented starch and glucose and produced lactic acid and acetic acid.

Twenty-eight strains of the slender rod-like organisms isolated from two sheep fed on the hay and FM diet and from two sheep fed on the hay and FM 2 diet were transferred to tomato agar medium (Rogosa, Wiseman, Mitchell \& Disraely, I953), in which they grew well anaerobically. On plating, colonies developed that were $3 \mathrm{~mm}$

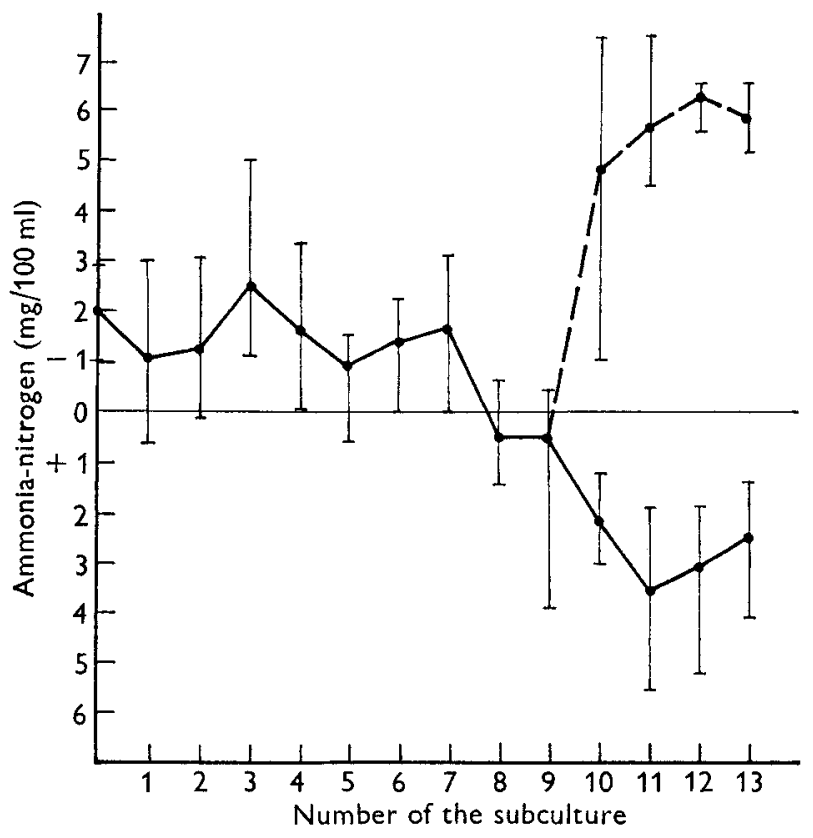

Fig. I. Mean values for the changes in ammonia-N in peptone media, $-\bullet$, and in:normal media, $--\cdots$, after incubation at $37^{\circ}$ under $\mathrm{CO}_{2}$ (for details of these media see p. 153). The media were initially inoculated with single colonies of starch-fermenting cocci and subcultured every 4-5 days. At the ninth subculture each culture was transferred to both peptone and normal media. The vertical lines indicate the range of values found in the nine cultures examined at the end of each incubation period.

in diameter, round, entire, very raised, convex in the centre and often thinner at the edges, white but opaque, especially in the centre. Sometimes the colour was closer to cream. They had a slightly mucoid consistency and were easily emulsified. Small translucent colonies, $0.5 \mathrm{~mm}$ diameter, were sometimes seen in tomato agar in roll tubes but they reverted to the standard type on subculture. They appeared to occur most frequently when the inoculum was taken from a poorly growing culture. Colonies from all strains were examined by the method of Bisset (1938). All the strains had a smooth configuration.

Rapidly growing cells were $0.7 \mu \times 3 \mu$ and occurred generally singly or in pairs. Most of them were Gram-positive but some Gram-negative cells were usually present. 
Adjacent cells tended to be at an angle to one another. Under apparently random conditions, branching occurred and on staining for cell walls (Hale, I953) it was seen that branching was not an artifact. Cells in older cultures tended to be pleomorphic and mostly Gram-variable. Large globular bodies, rods with swollen ends and thin filaments were common and Gram-positive granules were always observed.

The biochemical properties of each of the twenty-eight strains and of possible mutants isolated from sheep fed on hay with FM or FM 2 were examined and a reexamination of three strains was repeated 2 months later. All were negative for catalase, nitrate reduction, ammonia production from $0.3 \%$ arginine in tomato broth, and hydrolysis of aesculin and hippurate. All the strains grew in the presence of $2 \%(\mathrm{w} / \mathrm{v}) \mathrm{NaCl}$ but only $40 \%$ of them with $4 \%$ or $6 \% \mathrm{NaCl}$. Heat stability at $60^{\circ}$ for $\mathrm{I} h$ was variable. In yeast-glucose-litmus-milk the survival rate of all strains at $4^{\circ}$ irrespective of the incubation period was poor. The strains did not hydrolyse casein ( $\%$, light, soluble, British Drug Houses Ltd) or gelatin ( $0.3 \%$ in tomato agar plates). Hydrolysis was tested with acid mercuric chloride.

\section{Table 7. Fermentation reactions of strains of ammonia-utilizing Gram-positive rod-like bacteria (presumed to be Lactobacillus bifidus), from two series of experiments}

(For medium see p. 159 . Sugars were in I \% (w/v) concentration. Cultures were incubated anaerobically at $37^{\circ}$ for at least 12 days. Fermentation was assessed by the change in $\mathrm{pH}-$ see footnote)

\begin{tabular}{|c|c|c|c|c|c|c|c|c|c|c|}
\hline \multirow{3}{*}{ Sugar } & \multicolumn{10}{|c|}{ No. of strains fermenting carbohydrates } \\
\hline & \multicolumn{2}{|c|}{$\begin{array}{c}\text { Rapid } \\
\text { fermentation* } \\
(<5 \text { days }) \\
\text { series }\end{array}$} & \multicolumn{2}{|c|}{$\begin{array}{c}\text { Slow } \\
\text { fermentation* } \\
(>5 \text { days }) \\
\text { series }\end{array}$} & \multicolumn{2}{|c|}{$\begin{array}{c}\text { Weak } \\
\text { fermentation } \\
\text { series }\end{array}$} & \multicolumn{2}{|c|}{$\begin{array}{c}\text { No } \\
\text { fermentation } \neq \\
\text { series }\end{array}$} & \multicolumn{2}{|c|}{$\begin{array}{l}\text { Total } \\
\text { series }\end{array}$} \\
\hline & I & 2 & $\mathbf{I}$ & 2 & I & 2 & I & 2 & $\mathbf{I}$ & 2 \\
\hline Glucose & 37 & 4 & 一 & 2 & I & - & I & 一 & 39 & 6 \\
\hline Xylose & - & I & - & 一 & - & 一 & 39 & 5 & 39 & 6 \\
\hline Cellobiose & - & - & 14 & $\mathbf{I}$ & 7 & - & 18 & 5 & 39 & 6 \\
\hline Trehalose & 4 & $\mathbf{I}$ & 16 & 5 & I & - & I 8 & - & 39 & 6 \\
\hline$\alpha-\mathrm{Me}-\mathrm{D}$-glucoside & 5 & 2 & 15 & 3 & 一 & - & I9 & $\mathbf{I}$ & 39 & 6 \\
\hline Inulin & $\underline{-}$ & - & - & $\underline{-}$ & 3 & - & 2 & 6 & 5 & 6 \\
\hline Salicin & $\mathbf{I}$ & - & 2 & 一 & - & I & 2 & 5 & 5 & 6 \\
\hline$\alpha$-Me-D-mannoside & $e-$ & - & 二 & $\mathrm{t}$ & - & - & 5 & 5 & 5 & 6 \\
\hline
\end{tabular}

All strains in both series rapidly fermented lactose, laevulose, sucrose, melibiose, raffinose and maltose. None fermented sorbitol, rhamnose, mannitol or arabinose.

Of five strains in series $I$ and the six strains in series 2 tested, all fermented dextrin and galactose. None fermented dulcitol, sorbose or inositol.
$* \mathrm{pH}<5$, rarely $<4^{\circ}$.
$+\mathrm{pH}, 5 \cdot 0-5 \cdot 4$.
$\ddagger \mathrm{pH}, 5 \cdot 8 \cdot 6 \cdot 4$.

The results of sugar fermentations in the medium of Rogosa et al. (1953) are given in Table 7. It will be seen that nearly all the strains utilized the same sugars and variation between strains occurred only when adaptive fermentation was occurring, as with trehalose, $\alpha$-Me-D-glucoside, cellobiose, inulin and salicin.

Analysis of the products of fermentation and of the glucose fermented by six strains are given in Table 8. After incubation for 8 days $90-99 \%$ of the glucose present $(\mathrm{I} \cdot 52 \%, \mathrm{w} / \mathrm{v})$ was fermented; the quantity of acetic acid produced in $\mathrm{mm} / \mathrm{r} 00 \mathrm{ml}$ 
medium was about twice that of lactic acid, and over $70 \%$ of the latter when examined as the zinc salt was in the $\mathrm{L}(+)$ form in five of the six strains tested. This indicates that the lactic acid was $L(-)$ since the rotation of the zinc salts of lactic acid is the opposite to that of the free acid radical (Brin, Olson \& Stare, 1952). Carbon dioxide was not evolved and the greater part of the glucose that disappeared was accounted for as acetic and lactic acids (Table 8). The cultural, morphological and biochemical properties of the strains tested were compatible with those described for L. bifidus.

The complex normal medium was examined to find the constituents needed for optimal growth of one of the strains resembling $L$. bifidus. No growth occurred when ammonium chloride was replaced by sodium chloride. Similarly, no growth occurred if L-cysteine was omitted. Of other reducing agents tested in place of L-cysteine, L-ascorbic acid and sodium sulphide were ineffective in the concentrations used. Thioglycollate was less effective than L-cysteine except when a casein hydrolysate or methionine was added to the medium. Other amino acids-glycine, alanine or serine-did not improve growth in the presence of thioglycollate. Growth was judged by appearance of the culture, by the quantity of ammonia- $\mathrm{N}$ used and by the quantities of acetic and lactic acids produced during incubation for $7^{2} \mathrm{~h}$.

Table 8. Acids produced ( $m$-moles/100 ml medium) during the fermentation of glucose by six strains of ammonia-utilizing Gram-positive rod-like bacteria from the sheep rumen

(The cultures were grown in a modification of the medium of Baumann $\&$ Foster (1956) incubated at $37^{\circ}$ for 8 days (see p. 154))

$\begin{array}{cccc}\begin{array}{c}\text { Strain } \\ \text { no. }\end{array} & \begin{array}{c}\text { Glucose } \\ \text { utilized }\end{array} & \begin{array}{c}\text { Lactic } \\ \text { acid } \\ \text { produced }\end{array} & \begin{array}{c}\text { Acetic } \\ \text { acid } \\ \text { produced }\end{array} \\ \text { I2 } & 8 \cdot 3 & 7 \cdot 2 & \text { I } 16 \\ \text { I7 } & 7 \cdot 6 & 5 \cdot 2 & \text { I } \cdot 2 \\ \text { I8 } & 8 \cdot 3 & 6 \cdot 2 & \text { I2.9 } \\ 22 & 8 \cdot 3 & 7 \cdot 0 & \text { I } 15 \\ 28 & 8 \cdot 3 & 6 \cdot 9 & \text { I } 1 \cdot 6 \\ 20 & - & 6 \cdot 6 & \text { I } 1 \cdot 2\end{array}$

Of the other constituents of the medium, sodium citrate, valeric acid and isovaleric acid were unnecessary. The omission of sodium acetate slightly depressed growth. Omission of the B vitamins also produced slightly suboptimal growth after repeated subculture but the effect was variable. Omission of the trace elements from the medium markedly depressed growth but when the individual components were restored normal growth occurred with only the $\mathrm{Mg}$ and $\mathrm{Mn}$ salts; $\mathrm{Mn}$ was slightly less effective than $\mathrm{Mg}$.

\section{Colony counts of starch- and glucose-fermenting bacteria}

Colony counts varying from 60 to $55^{\circ}$ millions/ml rumen liquor were obtained on normal solid medium from two sheep fed on hay and FM on six occasions, and on peptone solid medium counts of 500-3000 millions/ml were obtained on three occasions. Liquor from a sheep fed on hay and FM2 gave counts on normal media of 
o-170 millions $/ \mathrm{ml}$ on three occasions and 590 millions $/ \mathrm{ml}$ on one occasion on peptone media. Liquor from a sheep fed on hay and G gave counts of 8-22 millions $/ \mathrm{ml}$ on four occasions on normal media and counts of the same order on peptone media, and liquor from the sheep fed on hay alone gave counts of $0-5$ millions $/ \mathrm{ml}$ on four occasions on normal media. From these results it was clear that considerable variability must be expected but further estimates might reveal definite trends in the colony count in relation to the diet eaten by the sheep. Three sheep were added to the five already examined so that two animals were available on each diet. Animals I, 2, 3, 5 and 7 had been on the experimental feeding régime for ro months or more but animals 4,6 and 8 were introduced to the diet only 4 weeks before counts were made. Four counts were made for each sheep with both normal and peptone media. Counts for sheep I, 3, 5 and 7 were made during the ist month and for sheep 2, 4, 6 and 8 over the and month. Two sheep were sampled on each occasion. The results are given in Table 9 and show very great variation.

Table 9. Concentration, as determined from two-figure plate counts on media containing ammonia, of organisms in rumen liquor of sheep receiving diets containing hay and various concentrates

\begin{tabular}{|c|c|c|c|c|c|c|}
\hline \multirow[b]{2}{*}{ Medium* } & \multirow{2}{*}{$\begin{array}{l}\text { Type of } \\
\text { concentrate† } \\
\text { in diet }\end{array}$} & \multirow[b]{2}{*}{ Sheep } & \multicolumn{4}{|c|}{$\begin{array}{l}\text { Concentration of rumen organisms } \\
\text { (millions/ml rumen liquor) }\end{array}$} \\
\hline & & & Count if & Count if & Count $3+$ & Count $4 \ddagger$ \\
\hline \multirow{4}{*}{$\begin{array}{l}\text { Normal (con- } \\
\text { taining ammonia } \\
\text { as almost the } \\
\text { sole source of } \\
\text { nitrogen) }\end{array}$} & FM & $\begin{array}{l}\mathrm{A} \\
\mathrm{B}\end{array}$ & $\begin{array}{c}\circ \\
720\end{array}$ & $\begin{array}{r}0 \\
217\end{array}$ & $\begin{array}{r}86 \\
1040\end{array}$ & $\begin{array}{r}\text { II } 60 \\
607\end{array}$ \\
\hline & $\mathrm{FM}_{2}$ & $\begin{array}{l}\mathrm{C} \\
\mathrm{D}\end{array}$ & $\begin{array}{r}160 \\
0\end{array}$ & $\begin{array}{r}440 \\
0\end{array}$ & $\begin{array}{l}30 \\
86\end{array}$ & $\begin{array}{l}94 \\
34\end{array}$ \\
\hline & G & $\begin{array}{l}\mathrm{E} \\
\mathrm{F}\end{array}$ & $\begin{array}{l}\mathbf{I} \\
0\end{array}$ & $\begin{array}{r}12 \\
1\end{array}$ & $\begin{array}{r}\text { II } \\
5\end{array}$ & $\begin{array}{l}5 \\
9\end{array}$ \\
\hline & None & $\begin{array}{l}\mathrm{G} \\
\mathrm{H}\end{array}$ & $\begin{array}{r}20 \\
I\end{array}$ & $\begin{array}{r}10 \\
6\end{array}$ & $\begin{array}{r}16 \\
6\end{array}$ & $\begin{array}{l}4 \\
5\end{array}$ \\
\hline \multirow{4}{*}{$\begin{array}{l}\text { Peptone (normal } \\
\text { medium with } \\
\text { added peptone) }\end{array}$} & FM & $\begin{array}{l}\mathrm{A} \\
\mathrm{B}\end{array}$ & $\begin{array}{l}2000 \\
1833\end{array}$ & $\begin{array}{l}227 \\
557\end{array}$ & $\begin{array}{r}53^{\circ} \\
1700\end{array}$ & $\begin{array}{r}200 \\
1960\end{array}$ \\
\hline & $\mathrm{FM}_{2}$ & $\begin{array}{l}\mathrm{C} \\
\mathrm{D}\end{array}$ & $\begin{array}{r}778 \\
\text { I }\end{array}$ & $\begin{array}{r}2300 \\
4 I\end{array}$ & $\begin{array}{l}233 \\
133\end{array}$ & $\begin{array}{r}260 \\
30\end{array}$ \\
\hline & G & $\begin{array}{l}\mathrm{E} \\
\mathrm{F}\end{array}$ & $\begin{array}{r}\mathrm{I} 4 \\
\mathrm{I}\end{array}$ & $\begin{array}{r}29 \\
2\end{array}$ & $\begin{array}{l}20 \\
10\end{array}$ & $\begin{array}{l}24 \\
46\end{array}$ \\
\hline & None & $\begin{array}{l}\mathrm{G} \\
\mathrm{H}\end{array}$ & $\begin{array}{r}20 \\
9\end{array}$ & $\begin{array}{r}24 \\
6\end{array}$ & $\begin{array}{r}17 \\
6\end{array}$ & $\begin{array}{r}6 \\
10\end{array}$ \\
\hline
\end{tabular}

This experiment must be considered as exploratory to systematic work on the variability of counts for rumen bacteria. It shows clearly that very large variation in one animal can occur; it suggests that the length of time an animal has been fed on a given diet may influence the count, since sheep 4,6 and 8 tended to have lower counts than those that had been given the diet for much longer periods. A statistical analysis of the results by A. W. Boyne of this Institute indicated that when period 
differences were eliminated the accuracy of the analysis was improved as far as peptone counts were concerned. The results of the analysis have been published previously (Phillipson et al. 1959), and the conclusions drawn were that in peptone counts the diets containing FM gave significantly higher values than those that did not $(P<0.05)$. The same trend was present in normal counts but was not significant.

\section{DISCUSSION}

The diets used in these experiments were designed to exaggerate the effects of a starch-rich food such as flaked maize or a protein-rich food such as groundnut meal on the ammonia concentrations present in the rumen and the changes that might be expected when the liquor was incubated in vitro.

The in vitro experiments demonstrated that assimilation of ammonia-N occurs in the mixed culture of bacteria present in the rumen liquor of sheep fed on fodder beet and in sheep given large quantities of flaked maize. It is reasonable to suppose that both assimilation of ammonia- $\mathrm{N}$ and the production of ammonia are going on simultaneously in the rumen liquor of sheep fed on any diet and that the relative speeds of these two processes will determine the concentrations present. These experiments represent only what may occur in the rumen liquor drawn shortly after feeding, and under these circumstances it appears that the presence of soluble carbohydrate is necessary for assimilation of ammonia- $\mathrm{N}$ to exceed production. The deaminative effects of rumen organisms have been studied in detail by El-Shazly $\left(195^{2} a, b\right)$ and Lewis (I955), proteolysis by Warner (1955) and the effects of different food proteins on the ammonia concentrations in the rumen by McDonald (1952), Chalmers \& Synge (1954) and Annison et al. (1954).

The values for ammonia concentration in the rumen fully confirm those of Annison et al. (1954) concerning the relative effects of starch and groundnut meal, since in the experiments reported here the mean values for ammonia concentration increased as the proportion of groundnut meal in the diet increased and the starch content decreased. The results for the in vitro incubations show that when flaked maize was given in very large quantities the rate of decrease of ammonia exceeded the rate of ammonia production, and that as the flaked-maize mixture was reduced in quantity and groundnut meal was increased the relative rates of disappearance and formation of ammonia changed until considerable net increases occurred within the short period of $2 \frac{1}{2} \mathrm{~h}$. When the individual results for the initial concentration of ammonia and the change in it were plotted against each other there was no close individual relationship between the two values for any of the diets.

Warner (1955) found that assimilation of ammonia- $\mathrm{N}$ by mixed rumen microorganisms could occur in vitro while the concentration of ammonia- $\mathrm{N}$ was increased, indicating that both processes proceed at the same time. The behaviour of isolated strains of starch- and glucose-fermenting bacteria is explicable in this way and the experiments described here are in keeping with those of Warner. Bryant (I96r) found that very few of the predominant strains of rumen bacteria required amino acids other than L-cysteine and that those that did require other amino acids belonged to the 
Bacteroides ruminicola group, although other strains of this group did not have this requirement.

It is still not clear whether L-cysteine was essential for the growth of organisms in normal medium solely on account of its reducing properties. The fact that L-ascorbic acid or sodium sulphide could not be used to replace L-cysteine suggests that it was acting also as an essential growth factor. Growth occurred with thioglycollate in place of L-cysteine although growth was not optimal unless casein hydrolysate or methionine was also present. This suggests that the presence of an acceptable SH group may be an essential growth factor, but that as methionine without L-cysteine or thioglycollate was ineffective in promoting growth a reducing agent may also be necessary. Methionine was also ineffective in the presence of L-ascorbic acid or sodium sulphide.

The organisms examined in detail had characteristics which suggest that they were L. bifidus, closely resembling the type $\mathrm{C}$ of Sundman, af Bjorksten \& Gyllenberg (1959). Norris, Flanders, Tomarelli \& György (1950) found that the proportion of lactic and acetic acids formed by a given strain of $L$. bifidus varied in different experiments, but that the proportion of lactic acid was always less than that of acetic. The lactic acid was mostly in the $\mathrm{L}$ form. Hassinen, Durbin, Tomarelli \& Bernhart (195I) showed that $L$. bifidus from infant faeces would grow in a medium with ammonium acetate as the principal source of nitrogen together with vitamins and cysteine. The cysteine or cystine was necessary for growth and could not be replaced by methionine or other organic or inorganic sulphur compounds. Some organisms classified as strains of $L$. bifidus have been isolated from the rumen. Wasserman, Seely \& Loosli (1953) isolated Gram-positive rods which utilized ammonia in the presence of cysteine but these differed from the organisms now considered in producing optically inactive lactic acid and in being less exacting in their source of sulphur. Baumann \& Foster (1956) isolated L. bifidus from the rumens of cows fed on lucerne hay; during incubation these organisms produced acetic and lactic acids in molar proportions of $2: \mathrm{I}$. The optical activity of the lactic acid produced and the ability of the bacteria to grow on ammonium salts alone were not determined. However, the media used for isolation by Wasserman $e$ t al. (1953) and Baumann \& Foster (1956) contained ammonium salts and cysteine as well as other sources of nitrogen. Clarke (I959) described an anaerobic, Gram-positive, non-sporing, branching rod closely resembling $L$. bifidus, isolated from the rumens of cows fed on fresh clover or clover hay. The characteristics described by Clarke were similar to those of the organisms from sheep examined by us, except that those isolated from the cow reduced nitrate to nitrite and produced optically inactive lactic acid; some fermentation reactions also differed. The concentrations were $20 \mathrm{millions} / \mathrm{ml}$ in one cow and 70 thousand $/ \mathrm{ml}$ in the other cow. These organisms could not be found in the cow's rumen during the winter when the food contained little sucrose. Clarke concluded that the organisms appear only under certain conditions. In our experiments organisms resembling $L$. bifidus were numerous only in sheep maintained on diets very high in starch.

The total concentration of bacteria in the rumen of the sheep was assessed from direct microscopic counts by Moir \& Williams (1950) to be as high as $25-65 \times 10^{9} / \mathrm{ml}$. 
If the total counts in our experiments were in the same range, the highest colony plate counts obtained represented only about $2-10 \%$ of the total population except that for the sheep fed on diets not containing FM they represented only $0.1 \%$ or less. In this assessment it is assumed that all the cells counted in a direct microscopic count are viable. Bryant \& Burkey (r953) compared microscopic counts with colony counts obtained with a medium designed to allow growth of all organisms that would accept glucose and cellobiose as a substrate. They found that the mean colony count was $\mathrm{I} \cdot 7 \pm 0 \cdot 45 \times 10^{9} / \mathrm{ml}$ compared with $20 \cdot 2 \pm 6 \cdot 1 \times 10^{9} / \mathrm{ml}$ for microscopic counts. The medium used by Bryant \& Burkey (I953) contained rumen fluid, ammonium salts and cysteine as sources of $\mathrm{N}$ and many of the bacteria growing on this medium will utilize ammonia as a source of $\mathrm{N}$ either with or without amino acids or peptides (Chu \& Bryant, 1958; Gill \& King, 1958; Gilroy, 1957). At least one type of cellulolytic organism from the rumen, Bacteroides succinogenes, has an absolute requirement for ammonia (Bryant, Robinson \& Chu, 1959). The properties of rumen micro-organisms to assimilate and produce ammonia- $\mathrm{N}$ are important in the utilization of $\mathrm{N}$-containing foodstuffs by ruminants, and the work of Bryant (1961), which is supported by the studies reported here, shows that a large number of bacteria in the rumen possess both properties. Changes in the concentrations of ammonia- $\mathrm{N}$ in the rumen in relation to the food eaten by the animal therefore seem to depend as much upon the nitrogenous and other substrates available as on any change in the concentrations of distinguishable bacteria present within the total bacterial concentration.

\section{SUMMARY}

I. The changes in ammonia-nitrogen concentrations occurring in the rumen liquor of sheep fed on different diets to which ammonium chloride had been added were studied during short in vitro incubations in an atmosphere of carbon dioxide.

2. Decreases in concentration usually occurred in the liquor of sheep fed on a diet containing large quantities of flaked maize, and small decreases occurred in the liquor of sheep fed on fodder beet and hay, drawn after feeding. Concentrations of ammonia- $\mathrm{N}$ in the liquor drawn before the sheep ate the fodder-beet diet increased to a small extent.

3. Adding groundnut meal to the flaked-maize diet resulted in increases in concentration of ammonia- $\mathrm{N}$ during incubation. As the quantity of groundnut meal added increased, so the concentrations increased both in the rumen and during in vitro incubation.

4. Neither penicillin, chlortetracycline nor sulphanilamide prevented a decrease in the ammonia- $\mathrm{N}$ in rumen liquor during $2 \frac{1}{2} \mathrm{~h}$ in vitro incubation.

5. Decreases in ammonia- $\mathrm{N}$ during incubation of rumen liquor were accompanied by an increase in compounds precipitated by trichloroacetic acid. When ${ }^{15} \mathrm{~N}$-labelled ammonium chloride was added to rumen liquor the heavy isotope was concentrated in the trichloroacetic acid precipitate and a substantial decrease in the ammonia- $\mathrm{N}$ occurred.

6. Starch- and glucose-fermenting bacteria isolated from the rumen assimilated 
ammonia- $\mathrm{N}$, from media containing $\mathrm{L}$-cysteine and $\mathrm{B}$ vitamins as other $\mathrm{N}$ sources, and produced acetic and lactic acids. Both cocci and slender rods were isolated and the latter proved to have properties similar to those described for Lactobacillus bifidus.

7. Cultures of starch- and glucose-fermenting bacteria also assimilated ammonia-N from these media in the presence of peptone. The decrease in ammonia concentration in the media was less rapid with peptone and, after repeated subculture, increases occurred.

8. Starch- and glucose-fermenting bacteria were generally more numerous in the rumen liquor of sheep receiving large quantities of flaked maize than in the liquor of sheep fed on hay or hay and groundnut meal. Pronounced exceptions, however, occurred on occasion.

We are grateful to Dr E. I. McDougall for the determination of ${ }^{15} \mathrm{~N}$, to $\operatorname{Dr} \mathrm{T} . \mathrm{M}$. Sutherland for the identification of the optical activity of the lactic acid, and to Mr R. S. Reid for the chromatographic determination of the acetic acid formed.

\section{REFERENCES}

Annison, E. F. (1954). Biochem. F. 57, 400.

Annison, E. F., Chalmers, M. I., Marshall, S. B. M. \& Synge, R. L. M. (1954). F. agric. Sci. 44, 270.

Barker, S. B. \& Summerson, W. H. (1941). F. biol. Chem. 138, 535.

Baumann, H. E. \& Foster, E. M. (1956). F. Bact. 71, 333.

Bisset, K. A. (1938). F. Path. Bact. 47, 223.

Brin, M., Olson, R. E. \& Stare, F. J. (1952). Arch. Biochem. Biophys. 39, 2 I4.

Bryant, M. P. (1961). U.S. Dep. Agric. Res. Service, ARS 44-92. (Mimeo.)

Bryant, M. P. \& Burkey, L. A. (1953). F. Dairy Sci. 36, 205.

Bryant, M. P., Robinson, I. M. \& Chu, H. (1959). F. Dairy Sci. 42, 183 I.

Chalmers, M. I. \& Synge, R. L. M. (1954). F. agric. Sci. 44, 263.

Chu, H. \& Bryant, M. P. (1958). F. Dairy Sci. 4r, 729.

Clarke, R. T. J. (1959). F. gen. Microbiol. 2o, 549.

Conway, E. J. \& O'Malley, E. O. (1942). Biochem. F. 36, 655 .

El-Shazly, K. (1952a). Biochem. F. 51, 640 .

El-Shazly, K. (1952b). Biochem. F. 51, 647 .

Gill, J. W. \& King, K. W. (1958). F. Bact. 75, 666.

Gilroy, J. J. (1957). Nitrogen requirements for growth of bovine rumen bacteria. Ph.D. Thesis, University of Maryland.

Hale, C. M. F. (1953). Lab. Practice, 2, 115.

Hassinen, J. B., Durbin, G. T., Tomarelli, R. M. \& Bernhart, F. W. (195 I). F. Bact. 62, 77 I.

James, A. T. \& Martin, A. J. P. (1952). Biochem. F. 50, 679.

Lewis, D. (1955). Brit. F. Nutr. 9, 2 I 5 .

McAnally, R. A. (1944). F. exp. Biol. 20, 130.

McDonald, I. W. (1952). Biochem. $\mathcal{F} . \mathbf{5 1}, 86$.

Moir, R. J. \& Williams, V. J. (1950). Aust. F. sci. Res. B, 3, 38 I.

Norris, R. F., Flanders, T., 'Tomarelli, R. M. \& György, P. (1950). F. Bact. 60, 68 I.

Pearson, R. M. \& Smith, J. A. B. (1943). Biochem. F. 37, I53.

Phillipson, A. T., Dobson, M. J. \& Blackburn, T. H. (1959). Nature, Lond., r83, 402.

Rogosa, M., Wiseman, R. F., Mitchell, J. A. \& Disraely, M. N. (I953). F. Bact. 65, 681.

Sundman, V., af Bjorksten, K. \& Gyllenberg, H. G. (1959). F. gen. Microbiol. 21, 371.

Warner, A. C. I. (I955). Some aspects of the nitrogen metabolism of micro-organisms of the rumen with special reference to proteolysis. Ph.D. Thesis, University of Aberdeen.

Wasserman, R. H., Seely, H. W. \& Loosli, J. K. (1953). F. Anim. Sci. 12, 935. 